\title{
Decoloniality and anti-oppressive practices for a more ethical ecology
}

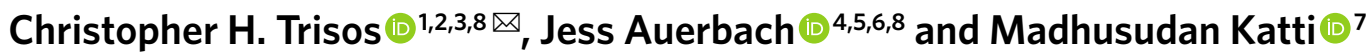

\begin{abstract}
Ecological research and practice are crucial to understanding and guiding more positive relationships between people and ecosystems. However, ecology as a discipline and the diversity of those who call themselves ecologists have also been shaped and held back by often exclusionary Western approaches to knowing and doing ecology. To overcome these historical constraints and to make ecology inclusive of the diverse peoples inhabiting Earth's varied ecosystems, ecologists must expand their knowledge, both in theory and practice, to incorporate varied perspectives, approaches and interpretations from, with and within the natural environment and across global systems. We outline five shifts that could help to transform academic ecological practice: decolonize your mind; know your histories; decolonize access; decolonize expertise; and practise ethical ecology in inclusive teams. We challenge the discipline to become more inclusive, creative and ethical at a moment when the perils of entrenched thinking have never been clearer.
\end{abstract}

T he growth of ecological science as an academic discipline is embedded within colonialism ${ }^{1}$. European ecologists benefited from colonial access to land for expeditions and establishment of field stations that helped, and continue to help, form foundational theories in ecology and evolution ${ }^{2,3}$. For example, use of the terms Neotropics or Neotropical in ecology journals continues to increase rapidly (Supplementary Fig. 1). But whose tropical New World is this, and to whom are these megadiverse regions really so new? The answer is embedded in the concept of scientific discovery that described the world from the perspective of post-enlightenment Europe $^{4,5}$ (Fig. 1). Moreover, insights from what would become Western scientific ecology were used to justify social and environmental control, including dispossessing colonized peoples of their land and ways of life and discounting existing knowledge systems. This benefitted colonial industries such as rubber, sugar and forestry that were critical to the emergence of the modern world order and ongoing violence of a global economic system largely based on extraction ${ }^{6,7}$.

Recognizing the diversity of members who make up the ecology research community today, more ecologists need to reflect on the consequences of this colonial legacy for the discipline moving forward. Many ecologists still rationalize that organisms and ecosystems can be understood when stripped of their human-related histories of unequal social, economic and ontological relations ${ }^{5}$. Yet, these unequal histories have shaped, and continue to shape, the Earth system. For instance, the large-scale death of around $90 \%$ of the Americas' Indigenous peoples as a result of European colonization is estimated to have resulted in successional vegetation growth on around $55 \mathrm{Mha}$ of disused land and a $3.5 \mathrm{ppm}$ drop in atmospheric $\mathrm{CO}_{2}$ before the Industrial Revolution ${ }^{8}$. An approach that continues to centre Western-trained scientists in understanding the world restricts research and limits ecology's ability to address environmental crises, because it fails to recognize a diversity of people, knowledge systems and solutions. Adverse reactions to the dominance of Global North voices regarding the potential for mass tree planting campaigns to mitigate climate change are one recent example ${ }^{9-11}$.

Recognizing that colonialism led to Euro-American centricity, dispossession, racism and ongoing power imbalances in how ecological research is produced and used is an important first step ${ }^{12}$. The next step is committing to decoloniality (meaning actively undoing those systems and ways of thinking), as opposed to post-coloniality (which is our historical reality and does not require taking responsibility for ongoing extractive, inequitable systems). Decolonization is not new. The work of scholars and activists from impacted places within the Global South (and North) towards undoing historical and ongoing systems of oppression over many generations must be acknowledged and amplified ${ }^{13-15}$.

The research, teaching and policy relevance of decolonizing ecology is profound. For example, the rise of social-ecological systems thinking has emphasized human-environment feedbacks ${ }^{16}$, but if differences in cultural values or worldviews are ignored, socialecological system approaches can actually damage people's perceptions of well-being by emphasizing vulnerability and directing blame towards local communities ${ }^{17,18}$. Moreover, from climate and environmental justice ${ }^{19}$ to conservation movements $\mathrm{s}^{20}$ and global environmental assessment ${ }^{21,22}$, it is increasingly recognized that inclusion of a diversity of worldviews on human-environment relations is necessary for a just transition to a more sustainable world.

Here, we outline five positive interventions to help build a more anti-oppressive and decolonial ecology (Fig. 2). In doing this, we recognize that the work of decoloniality and promoting inclusive excellence cuts across multiple dimensions of power and privilege, including (among others): race; gender; sexuality; nationality; institutional and socioeconomic status; neurodiversity; and passport positionality (that is, the countries one can visit without a visa and

\footnotetext{
'African Climate and Development Initiative, University of Cape Town, Cape Town, South Africa. ${ }^{2}$ Centre for Statistics in Ecology, the Environment and Conservation, University of Cape Town, Cape Town, South Africa. ${ }^{3}$ National Socio-Environmental Synthesis Center, University of Maryland, Annapolis, MD, USA. ${ }^{4}$ Department of Anthropology, North-West University, Potchefstroom, South Africa. ${ }^{5}$ Critical Studies in Higher Education Transformation, Nelson Mandela University, Gqeberha, South Africa. ${ }^{6}$ OBTENTIA Research Focus Area, North-West University, Vanderbijlpark, South Africa. ${ }^{7}$ Department of Forestry and Environmental Resources, North Carolina State University, Raleigh, NC, USA. ${ }^{8}$ These authors contributed equally: Christopher H. Trisos, Jess Auerbach.凶e-mail: christophertrisos@gmail.com
} 


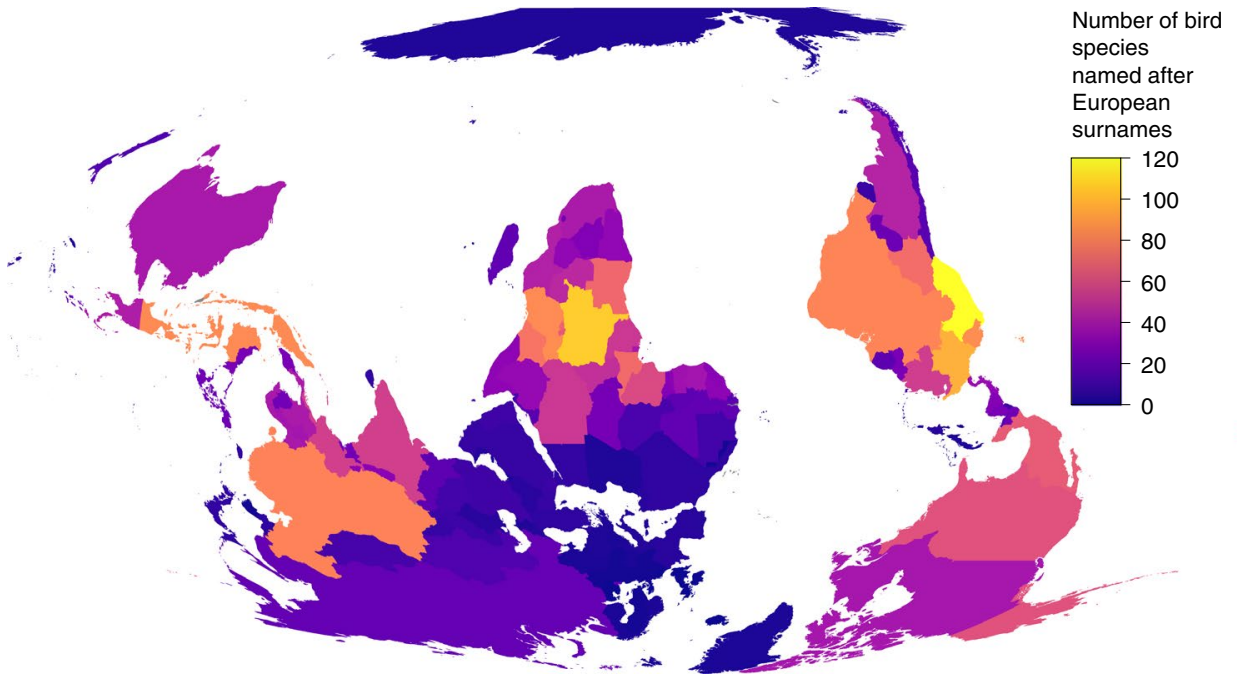

Fig. 1 | The fingerprint of colonialism on ecology today. Map showing the minimum estimate for each country of the number of bird species for which the Latin binomial name is based on a European person. Hundreds of bird species have been named after European surnames, with most of these species occurring outside Europe in formerly colonized countries. Taxonomy is used to organize the world into recognizable units, and taxonomists frequently name species after colleagues or wealthy patrons from the Global North. However, these names often carry little ecological information compared with pre-existing Indigenous names related to species habits and uses. More researchers are now using local languages spoken where a species is found when assigning binomial names, as well as examining taxonomic protocols in order to reinstate Indigenous names ${ }^{73,104}$. This practice encourages science storytelling in native languages and increases inclusion and participation in ecological research and knowledge. Bird species names and expert-verified geographic ranges were downloaded from the International Union for Conservation of Nature website (https://www.iucnredlist.org/). To estimate the number of bird species named after Europeans, we downloaded the names and affiliated countries of ornithologists and mammologists recorded on Wikipedia, as well as a list of the most common surnames in Europe (see 'Data availability'). These names were then compared with both the genus name and species epithet for each species to identify matches. All matches were checked individually and common surnames leading to multiple matches where the species may not have been named after a specific person were removed, including Gallo, Galli, Collis and Marin. The number of species named after European last names was then mapped at the country level.

the strength of the associated currency). Through exploring these actions, we aim to promote ways of practising ecology that are more creative, reflective, equitable, inclusive and effective. We note that these actions are not offered as a checklist capable of undoing unjust systems worldwide, nor to overshadow long histories of place-based anti-colonial and anti-racist struggle, but as connection points to action for practising ecologists.

\section{Decolonize your mind}

There are multiple ways of knowing. By not engaging diverse knowledge systems, ecological researchers limit their own knowledge and limit the potential impact of their work. Scholars from colonized backgrounds have often had to become ontologically conversant across multiple knowledge systems in order simply to be heard in ecology ${ }^{23}$. The same effort has not been required of largely white, Western establishment ecologists. The labour of this work must be rebalanced.

First, language shapes how we think about and understand the world ${ }^{24}$, and modern English emerged in the context of empire ${ }^{25}$. Although it was not always the case, since the twentieth century, English has been the dominant form of knowledge communication in science ${ }^{26,27}$, which can lead to publication bias against non-native English-speaking scientists ${ }^{28}$. When one reads, writes and thinks in English, it is easy to forget that for the majority of people ecological knowledge is produced and tested in other tongues 5 . For instance, the separation of rational self (culture) and wild nature in English language thinking is a result of post-Enlightenment rationality as an historical process, and is sociological and cultural, not empirical ${ }^{29}$. In contrast, nature is relational in many other languages. For example, the isiXhosa root word for the environment is difficult to translate into English. Indalo means both creation and nature. Kwezendalo means of or in the environment. Umdali is the creator. The implication is that people (abantu) are located within the environment.
Recent Western ecological concepts such as social-ecological or coupled human-natural systems are therefore already the de facto way of thinking in many non-European languages ${ }^{30,31}$.

Linguistics has clearly demonstrated that multilingualism expands what it is possible to imagine ${ }^{32}$ and languages provide rich insight into underlying processes that drive patterns of biodiversity ${ }^{33}$. Knowledge holders often need to speak their own language to accurately describe ecological concepts and classifications: using multiple languages can yield richer biological descriptions ${ }^{34,35}$. Moreover, ignoring non-English language studies can bias meta-analyses, and many local decision-makers do not speak English ${ }^{36,37}$. Ecological scholarship must develop methods to include multiple languages in evidence synthesis (for example, the translatE project; https://translatesciences.com/research/), and ecology, like many social sciences, could require that scholars gain fluency in relevant languages as an essential entry point for understanding rich bodies of local knowledge on ecosystems and cultivating a more inclusive epistemology. It is ironic that in many ecology departments, knowing Latin names of species is met with admiration, whereas speaking living languages of sites of data origination is a 'nice-to-have' skill.

Second, there are multiple ways of sharing information but peer-reviewed journals are typically limited to knowledge that can be written or graphed. The same is true of major environmental assessments for policymakers. As such, ecological knowledge systems embodied in artefacts, oral traditions and what anthropologists refer to as skill are left out ${ }^{38}$. For instance, Polynesian navigators crossed vast oceans using models made from shells and curved sticks that describe how ocean swells interact with land ${ }^{39}$. Much of Africa's long intellectual history has only recently begun to be recorded through text ${ }^{40}$. Thus, ecologists exposed only to written sources risk limiting their knowledge to the institutions of colonization and post-coloniality. 


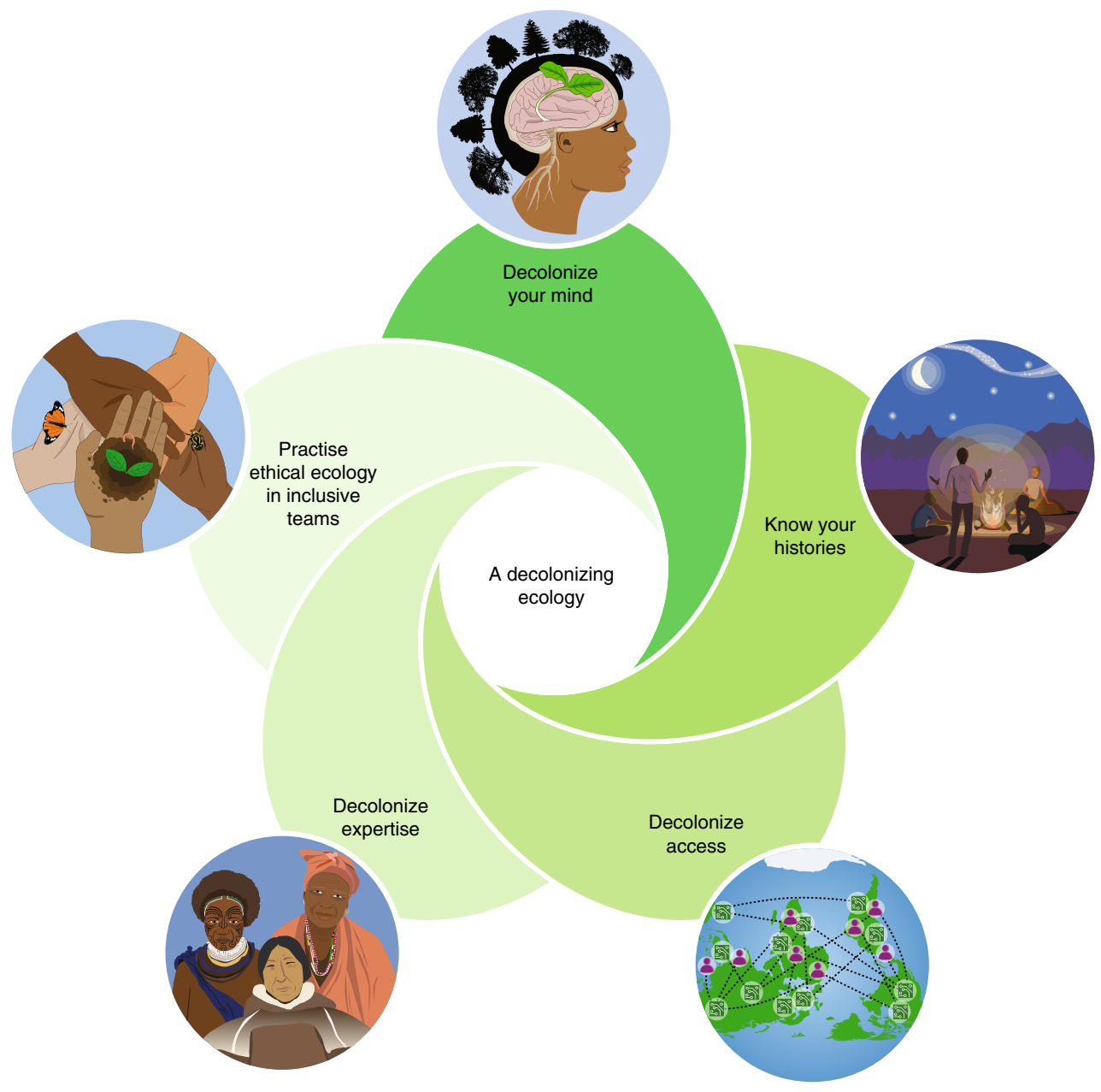

Fig. 2 | Five practices for decoloniality in ecology. These shifts are not exhaustive or a checklist, but are presented as positive interventions to promote ways of knowing and practising ecology that are more creative, reflective, equitable, inclusive and effective in aiding a just transition to a more sustainable world: 'decolonize your mind' to include multiple ways of knowing and communicating science; 'know your histories' to acknowledge our discipline's role in enabling colonial and ongoing violence against peoples and nature, and begin processes of restorative justice; 'decolonize access' by going beyond open access journals and data repositories to address issues of data sovereignty and the power dynamics of research ownership; 'decolonize expertise', by amplifying diverse expertise in ecologies and giving due credit and weight to that knowledge; and 'practice ethical ecology in inclusive teams', by establishing diverse and inclusive research teams that actively deconstruct biases so all team members are empowered participants in developing new knowledge. These actions support reformulating research questions and processes for a decolonizing ecology. Credit: Keren Cooper (illustrations).

Inclusion of more diverse forms of knowledge in ecological research, teaching and applied work is already being done and should be expanded further. The use of art helps to increase communication on interlinked biological and cultural diversity (for example, illustrations of caribou intraspecific variation and traditional hunting techniques provided insight into unique ecologies and sustainable management practices ${ }^{41}$ ). Similarly, storytelling can help to facilitate knowledge exchange and support dialogue for conservation practices ${ }^{42}$. Going beyond text in this way enables more inclusive, detailed and careful attention to diverse representations of knowledge. This also applies to ecologists themselves, who experience the world through their bodies-gendered, raced and often nationalized. Doing this helps to ensure that the interests knowledge serves are expanded to include those who might not otherwise participate in scientific discourse (Box 1).

\section{Know your histories}

For most of the world, colonialism was an enormously violent process tied to environmental degradation. South Africa's Archbishop Emeritus Desmond Tutu often quips: "When the colonists arrived, we had the land and they had the bible. Now we have the bible and they have the land!". Usually, when Tutu says this he is laughing, and audiences around the world have laughed with him. But his point has a powerful edge. Many modern ecologists may feel that time or desk-based research isolate them from this legacy. Yet, systems of colonial and ongoing trauma continue to shape the experience of many ecologists today, such as higher death rates from COVID19 among Black and Indigenous people and people of colour in Anglo-settler societies ${ }^{43}$ or racism experienced during fieldwork ${ }^{44}$ and spending time outdoors ${ }^{45}$.

It is vital to recognize that systemic inequalities (of race, access and opportunity) have defined the fields we know today, but that this is not an historic inevitability and can be changed. Western ecological knowledge has been used to displace people from their homes for settler-colonial conservation projects ${ }^{46}$ or otherwise restrict or demean their traditional practices such as the gathering of foods and medicine ${ }^{47}$. This legacy also persists in the militarization of anti-poaching operations ${ }^{48}$, and in climate change mitigation proposals from the Global North for extensive tree planting campaigns in grassy biomes in Africa that are viewed as deforested 


\section{Box 1 | Many ways of knowing and doing ecology}

There are a growing number of positive examples where Indigenous communities have used the tools of Western science to document and advance their own understanding of local ecologies and apply that knowledge to redress harms from past colonization and to improve the management of natural resources ${ }^{105,106}$. For example, the Amazon Conservation Team works with Indigenous communities in several South American countries in participatory projects to promote self-governance and biodiversity conservation. They have developed a methodology of collaborative cultural mapping ${ }^{107}$ by providing technology such as mobile phones and apps to Indigenous communities. The Kogi people, among the last surviving civilizations from the pre-Columbian period started using a mobile phone app to create geo-referenced maps of their land within the framework of their own cultural knowledge, resulting in a richer dataset than a parachuting Western ecologist or conservationist might be able to gather. In Kenya, the Ogiek community (Indigenous people from Chepkitale National Reserve) are using participatory three-dimensional modelling to integrate local spatial and natural resource knowledge with geographic information systems and physical modelling ${ }^{108}$. Their goal is to use the resulting maps and models to force the Kenyan government to formally recognize their customary land tenure, and to apply their traditional knowledge and practices to improve the management of the reserve. A recent study found that Indigenous managed lands in Australia, Brazil and Canada support more threatened vertebrate species and slightly higher vertebrate species richness than protected areas ${ }^{109}$, leading to the conclusion that partnerships with Indigenous communities have the potential to improve conservation outcomes globally ${ }^{110}$.

Research partnerships that use Indigenous-led technologies for data collection ${ }^{111}$ and embed Indigenous principles into research questions, analysis and management outcomes often result in more detailed ecological understanding, improve biodiversity and ensure sovereign human rights ${ }^{112-114}$-all providing strong arguments for this decolonial praxis in ecology.

Collaborations between artists and scientists and between Indigenous people and colonizers can result in even more creative ways to exchange and mutually enrich knowledge and understanding through innovative art-science projects such as Becoming Sensor in Sentient Worlds ${ }^{115}$, a kinaesthetic and visual exploration of the ungrid-able ecology of oak savannahs of Toronto's High Park. Science-art collaborations can help to bridge cultural gaps and improve understanding of Indigenous knowledge by harnessing the power of sound, visuals and storytelling ${ }^{116,117}$, and to communicate the urgency of climate change $\mathrm{e}^{118,119}$.

or degraded, despite these ancient landscapes supporting herds of megafauna and livelihoods for hundreds of millions of people ${ }^{10,11}$. When undergraduates in South Africa called for the decolonizing of the sciences (popularly, \#RhodesMustFall), they were not saying that science is wrong, but rather drawing attention to power structures within the sciences that have, in many moments of history, been disempowering for some bodies more than others ${ }^{49}$.

A practice more ecologists can immediately embrace is to offer a Territorial or Land Acknowledgement, which is a formal statement paying respect to the pre-colonial inhabitants of the land where a gathering or research work is taking place ${ }^{50,51}$. Ecologists can start talks or conferences this way, as some are already doing, but also go further by including this acknowledgement in publications, where the land itself might be a co-author, to more accurately reflect Indigenous modes of acknowledgement ${ }^{52,53}$. Land acknowledgements demonstrate respect for colonized peoples, and also push ecologists (and others) to consider histories of ongoing influence in ecosystems forcefully depopulated by colonialism that are too often studied as wilderness, such as national parks ${ }^{54}$. For instance, ecologists have worked with archaeologists and anthropologists to recognize the central role of pre-Columbian plant domestication in shaping modern Amazonian forest composition ${ }^{55}$. Land acknowledgements help to set a precedent for powerful institutions of Western science to reckon with their own abusive histories, and begin processes of restorative justice within the practice of the sciences.

Another important way to acknowledge history is to ensure that deep listening to colleagues, students and community representatives takes place ${ }^{56,57}$. Deep listening entails listening respectfully and responsibly in ways that build community and reciprocity. It involves taking time to build trust and incorporates multiple ways of knowing in order to ensure that whatever research is done is grounded in scientific curiosities, understandings of local contexts and needs, and awareness of ongoing extractive systems that may shape decisions (Box 1).

Deeper engagements with the history and philosophy of science, as well as the biographic histories of those practising ecology, are also needed as part of fundamental disciplinary training. This is necessary to allow ecologists to position themselves as situated parts of the systems they describe, rather than neutral actorsa view that has been robustly critiqued ${ }^{5}$. One concrete step is to identify the gaze (who we imagine we write for) and the pose (the standpoint from which we write) that we adopt in our work ${ }^{58}$. For example, self-reflection on whether a paper on biodiversity protection is being written by a foreign or local researcher and for a foreign or local audience can help the author and readers better place the paper's purpose. These choices are often made unconsciously and not declared, but they should be-a practice that is increasingly used in global health research ${ }^{58}$. Foreignness in this context can be defined by ethnicity, wealth, caste, geography, gender, spirituality and socioeconomic status, among others. Another way ecologists can critically reflect on their background and training (whatever the degree of privilege), and how these influence the questions they ask, the way they interpret data and who benefits, is by including a positionality statement in their publications. This practice has been suggested for field ecology and biogeography ${ }^{3,59}$. We have included one at the end of this article.

\section{Decolonize access}

Access to scholarly literature remains a pressing global issue and scholars in under-resourced institutions are often compelled to use pirate websites to read scientific publications ${ }^{60}$. Habitual law breaking should not be a requirement of scientific practice. An accepted solution is to publish only open access but the challenges of uneven terrain go much deeper.

Vast quantities of ecological data are collected on and in the Global South but stored in museums and on servers located in the Global North, where they may remain difficult to access for researchers without access to elite academic networks, substantial funding or high-speed Internet ${ }^{61}$. When new knowledge is the primary currency, ecologists must grapple with the ethical implications of systems that extract data but provide wide access only after authorship potential has been exhausted by researchers in the Global North. No one likes a parachute scientist ${ }^{62,63}$.

Part of the solution is to continue to make more data available faster, and to reject parachute science by including researchers from places where data were collected throughout the research process from design to disseminating results, including some secondary analyses $^{63-65}$. However, this participation is not enough. Existing power imbalances must also be addressed through increased funding and support for Black and Indigenous researchers and people 
of colour to lead programmes of data collection and analysis and hold data repositories in the Global South. Nevertheless, access to wealthy countries will still be essential for research work, because these are the places where high-level meetings usually take place, where sophisticated equipment is maintained, where some important museum collections are housed and where major funders are located. Therefore, we propose a reciprocal exchange: for every researcher from a wealthy nation who travels to a low- or middle-income country, a researcher from that country should be admitted to undertake similar work in and with the Global North.

Securing the data rights of collaborators providing data by recognizing their data sovereignty is another essential step ${ }^{66}$. Data sovereignty necessarily requires that Indigenous communities have the power to determine data access through their right to informed refusal for a research project ${ }^{67}$, and that data collection be performed by or jointly with local people so that data ownership and use support their priorities. For instance, when existing statistical or mapping frameworks for data collection and use do not reflect local priorities, these can be adapted or new approaches developed using participatory research practices that yield deeper ecological insights and improved biodiversity management ${ }^{68}$ (Box 1). The implications are that some data may become more restricted, yet this is an important act of reclaiming for those who have repeatedly been compelled to give on demand of their lifeways and territories. When permission is granted to work within such sites, credit must be given and outputs must be produced that are mutually beneficial $^{69,70}$.

\section{Decolonize expertise}

Non-Western knowledges have often been regarded as native, Indigenous or anecdotal and thereby marginalized, and white supremacy has suppressed contributions to ecology by those who do not fit the image of a scientist or who challenge a Western worldview $^{71-73}$. There are also multiple examples where Western scientists have claimed discoveries for knowledge that resident experts already knew and shared ${ }^{74}$. This demonstrates not a lack of knowledge itself but rather that, for many scientists raised in Western society, poor education concerning histories of systemic oppression has been by $\operatorname{design}^{75,76}$

Expert knowledge is a term many ecologists (both those who would identify with the term Western and those who do not) self-apply with some enthusiasm. The task is to amplify this diverse excellence. When Indigenous or localized knowledges are treated as expert knowledge ${ }^{77}$, the pool of available knowledges widens radically $^{78}$. With this widening comes the imperative to ensure the right experts are in the room and to cite sources correctly. Amplifying voices and thought from the Global South is another important step to transform a status quo in which mostly authors from the Global North write with an assumption of generality ${ }^{79}$. Similarly, ecology curricula, reading and reference lists that actively include the intellectual contributions of women, LGBTQI+ people, people of colour and the neurodiverse are essential in order to more accurately reflect both the history and future of ecological science ${ }^{72,75,80,81}$.

This broadening of expertise is essential for understanding and addressing urgent environmental challenges. It strengthens the evidence base for policy ${ }^{82}$ and increases the legitimacy and inclusivity of decision-making ${ }^{22}$. Indeed, the Intergovernmental Science-Policy Platform on Biodiversity and Ecosystem Services and Convention on Biological Diversity already explicitly support consideration of a diversity of knowledge systems in biodiversity assessments and policy-making ${ }^{21,22}$, although this is not without resistance ${ }^{83}$.

However, decolonizing expertise is not simply a matter of amplifying a diversity of expert perspectives. Power dynamics within institutions often replicate and reinforce the status quo of influence through peer review, performance metrics, grant funding and definitions of professional behaviour ${ }^{84,85}$. Institutional cultures that are exclusionary and damaging to certain bodies and minds must continue to be transformed, and those in positions of privilege must proactively and authentically engage in positive interventions to decentre themselves and open space for others. Work has been done on sexual harassment in the discipline thanks to the \#MeToo movement ${ }^{86}$, but much more is still needed. Greater awareness of implicit biases for all researchers is an important step, as is adopting anti-racist and related strategies that target injustice and increase safety and equity at all levels, including classrooms, laboratories, conferences, fieldwork and applied practitioner work ${ }^{72,87}$.

The desired result of this process will be a more equitable distribution of decision-making power and access to resources, meaning that those of us who work from positions of privilege must ask ourselves honestly: how can we open up our power to others? This is not a question of sacrifice, but a question of acknowledgement of authority. Who speaks first? Who makes decisions? Who drives research funding agendas? Particularly for white-bodied researchers at well-funded universities and other organizations funded by corporate wealth from resource extraction, giving up a power and voice that has been explicitly and implicitly reinforced for at least 500 years will not be easy.

\section{Practise ethical ecology in inclusive teams}

To build knowledge-sharing processes that are equitable and empowering, ensuring mutual translation and co-production at every step of the research process is essential ${ }^{88}$. This is critical for ecology to contribute bodies of knowledge that are legitimate, credible and usable for decision-making to benefit people and the ecosystems we inhabit ${ }^{38}$.

To address this challenge, establishing diverse and inclusive research teams that actively deconstruct biases so that all team members are empowered participants in developing new knowledge is essential. Diverse teams result in more innovative and effective problem solving ${ }^{89,90}$. To be successful, collaboration also requires careful listening ${ }^{56,91}$, a willingness to grow in potentially unexpected directions ${ }^{92}$ and awareness of practical challenges not only from disciplinary differences ${ }^{93}$ but also structural limitations such as visa or Internet restrictions that may impact certain team members more than others ${ }^{94}$. Long-term commitments to the well-being of populations outside of Euro-America also matter.

The framework of intersectionality was introduced to social theory by Crenshaw ${ }^{95}$, and we argue that it could be more effectively adopted within ecology. Intersectionality acknowledges the multiple intersecting dimensions of life experience that shape an individual's capacity to contribute to public and scholarly discourse, including: race/ethnicity, gender, nationality, indigeneity, wealth, spirituality, sexuality, parenthood/dependencies and other identities. An intersectional approach to practising ecology recognizes the multiple barriers and opportunities facing those working together as collaborators and is a call to action to develop long-term solutions for equitable research relationships.

Funding and reward structures must also change. Creating a more inclusive ethical practice of ecology requires institutions to change incentives away from individualistic perspectives and towards recognizing contributions that build knowledge collectively. One positive shift that is underway in some institutions is faculty tenure committees equally valuing articles where a candidate is not a lead or corresponding author but has made a substantial contribution, enabling those in privileged research institutions to more readily give up prominent authorship positions ${ }^{96}$. A further step is to use models for large teams that do away with lead authorship altogether ${ }^{97}$. Tenure and hiring committees should also regard science-policy translation for environmental justice, as well as efforts to diversify ecological sciences, as seriously as publication records ${ }^{72}$. This should include valuing the mentorship of trainees not based at Western institutions. 


\section{Conclusion}

Considering these five actions calls for reformulating research questions and practices as part of a decolonizing ecology that rejects extractive knowledge and instead generates knowledge that nurtures positive reciprocity with nature. Because settler-colonial processes have increased the vulnerability of people and other species by displacing them into unfamiliar or lower-quality landscapes ${ }^{98}$, the concept of ecological vulnerability to global change now intersects with environmental justice ${ }^{99,100}$. A decolonial ecological ethic would have ecologists examining the colonial and pre-colonial histories of the hypotheses they set out to test, the aims of their research for benefiting vulnerable species and communities, and the way their work intersects with corporate power and interests of extraction ${ }^{101}$. Analysis of change in socioecological systems must consider the impacts of colonial histories and offer solutions in a decolonial framework. Who is empowered to shape research questions is unsurprisingly who can shape research answers ${ }^{89,102}$, but this power dynamic is rarely considered in ecology. More opportunities for historically marginalized groups to set research agendas is an important way of redressing ongoing power imbalances.

We caution that the actions we outline are a beginning, not a checklist, for a decolonial ecology. We invite readers to make these shifts in their capacity as ecological researchers, teachers and practitioners. Although not simple, we believe these actions could prove defining, especially when ecology may emerge as a key discipline informing a future that disrupts, rather than entrenches, dynamics of inequality and helps lead a just transition to a more sustainable world.

\section{Data availability}

All of the data used are publicly available. Bird species names and geographic ranges are available at https://www.iucnredlist.org/ resources/spatial-data-download. The names of European ornithologists and mammologists are available at https://en.wikipedia.org/ wiki/List_of_ornithologists and https://en.wikipedia.org/wiki/List_ of_mammalogists, respectively. The most common European last names are available at https://en.wikipedia.org/wiki/List_of_most_ common_surnames_in_Europe. A revised list of European names used for matching to bird species names is available at Figshare (https://doi.org/10.6084/m9.figshare.14134277.v1).

\section{Code availability}

Code for matching European names with bird species names is available at Figshare (https://doi.org/10.6084/m9.figshare.14134277.v1).

Received: 20 November 2020; Accepted: 31 March 2021;

Published online: 24 May 2021

\section{References}

1. Kean, S. Historians expose early scientists' debt to the slave trade. Science https://doi.org/10.1126/science.aax5704 (2019).

2. Raby, M. American Tropics: The Caribbean Roots of Biodiversity Science (UNC Press Books, 2017).

3. Baker, K., Eichhorn, M. P. \& Griffiths, M. Decolonizing field ecology. Biotropica 51, 288-292 (2019).

4. Grove, R. H. Green Imperialism: Colonial Expansion, Tropical Island Edens and the Origins of Environmentalism (Cambridge Univ. Press, 1996).

5. Green, L. Rock|Water | Life: Ecology and Humanities for a Decolonial South Africa (Duke Univ. Press, 2020).

6. Ravi Rajan, S. Modernizing Nature: Forestry and Imperial Eco-development 1800-1950 (Oxford Univ. Press, 2006).

7. Anker, P. Imperial Ecology: Environmental Order in the British Empire, 1895-1945 (Harvard Univ. Press, 2002).

8. Koch, A., Brierley, C., Maslin, M. M. \& Lewis, S. L. Earth system impacts of the European arrival and great dying in the Americas after 1492. Quat. Sci. Rev. 207, 13-36 (2019).

9. Griscom, B. et al. Trees as nature-based solutions. One Earth 2, 387-389 (2020).

10. Ratnam, J. et al. Trees as nature-based solutions: a global south perspective. One Earth 3, 140-144 (2020).
11. Bond, W. J., Stevens, N., Midgley, G. F. \& Lehmann, C. E. R. The trouble with trees: afforestation plans for Africa. Trends Ecol. Evol. 34, 963-965 (2019).

12. Specht, J. Red Meat Republic: A Hoof-to-Table History of How Beef Changed America (Princeton Univ. Press, 2019)

13. Fanon, F. Black Skin, White Masks (Paladin London, 1970).

14. Césaire, A. Discourse on Colonialism (Monthly Review Press, 1972).

15. Smith, L. T. Decolonizing Methodologies: Research and Indigenous Peoples (Zed Books, 2013).

16. Folke, C., Biggs, R., Norström, A. V., Reyers, B. \& Rockström, J. Socialecological resilience and biosphere-based sustainability science. Ecol. Soc. 21, 41 (2016).

17. Sterling, E. J. et al. Biocultural approaches to well-being and sustainability indicators across scales. Nat. Ecol. Evol. 1, 1798-1806 (2017).

18. West, P. Dispossession and the Environment: Rhetoric and Inequality in Papua New Guinea (Columbia Univ. Press, 2016).

19. Dahir, I. A Ugandan climate activist was cropped out of a news agency photo of Greta Thunberg at Davos. BuzzFeed https://www.buzzfeednews. com/article/ikrd/vanessa-nakate-greta-thunberg-davos (2020).

20. Sandbrook, C., Fisher, J. A., Holmes, G., Luque-Lora, R. \& Keane, A. The global conservation movement is diverse but not divided. Nat. Sustain. 2 316-323 (2019).

21. Díaz, S. et al. The IPBES Conceptual Framework-connecting nature and people. Curr. Opin. Environ. Sustain. 14, 1-16 (2015).

22. Tengö, M. et al. Weaving knowledge systems in IPBES, CBD and beyond-lessons learned for sustainability. Curr. Opin. Environ. Sustain. 26-27, 17-25 (2017)

23. Kimmerer, R. W. Braiding Sweetgrass: Indigenous Wisdom, Scientific Knowledge and the Teachings of Plants (Milkweed Editions, 2013).

24. Mathiot, M. Ethnolinguistics: Boas, Sapir and Whorf Revisited (Mouton, 1979).

25. wa Thiongo, N. Decolonising the Mind: The Politics of Language in African Literature (East African Educational Publishers, 1986).

26. Gordin, M. D. Scientific Babel: How Science Was Done Before and After Global English (Univ. Chicago Press, 2015).

27. Montgomery, S. L. Does Science Need a Global Language? English and the Future of Research (Univ. Chicago Press, 2013).

28. Clavero, M. Unfortunately, linguistic injustice matters. Trends Ecol. Evol. 26, 156-157 (2011).

29. Tsing, A. L. The Mushroom at the End of the World: On the Possibility of Life in Capitalist Ruins (Princeton Univ. Press, 2017).

30. Richard Atleo, E. Tsawalk: A Nuu-chah-nulth Worldview (UBC Press, 2007)

31. Coscieme, L. et al. Multiple conceptualizations of nature are key to inclusivity and legitimacy in global environmental governance. Environ. Sci. Policy 104, 36-42 (2020).

32. Diamond, J. The benefits of multilingualism. Science 330, 332-333 (2010).

33. Ragupathy, S., Newmaster, S. G., Murugesan, M. \& Balasubramaniam, V. DNA barcoding discriminates a new cryptic grass species revealed in an ethnobotany study by the hill tribes of the Western Ghats in southern India. Mol. Ecol. Resour. 9, 164-171 (2009).

34. Polfus, J. L. et al. Łeghágots'enetę (learning together): the importance of Indigenous perspectives in the identification of biological variation. Ecol. Soc. 21, 18 (2016).

35. Stronen, A. V. et al. Population genetic structure of gray wolves (Canis lupus) in a marine archipelago suggests island-mainland differentiation consistent with dietary niche. BMC Ecol. 14, 11 (2014).

36. Konno, K. et al. Ignoring non-English-language studies may bias ecological meta-analyses. Ecol. Evol. 10, 6373-6384 (2020).

37. Amano, T., González-Varo, J. P. \& Sutherland, W. J. Languages are still a major barrier to global science. PLoS Biol. 14, e2000933 (2016).

38. Ingold, T. The Perception of the Environment: Essays on Livelihood, Dwelling and Skill (Psychology Press, 2000).

39. Genz, J. Navigating the revival of voyaging in the Marshall Islands: predicaments of preservation and possibilities of collaboration. Contemp. Pac. 23, 1-34 (2011).

40. Blackhawk, N. \& Wilner, I. L. Indigenous Visions: Rediscovering the World of Franz Boas (Yale Univ. Press, 2018).

41. Polfus, J. L. et al. Creative convergence: exploring biocultural diversity through art. Ecol. Soc. 22, 4 (2017).

42. Fernández-Llamazares, Á. \& Cabeza, M. Rediscovering the potential of Indigenous storytelling for conservation practice. Conserv. Lett. 11, e12398 (2018)

43. Tai, D. B. G., Shah, A., Doubeni, C. A., Sia, I. G. \& Wieland, M. L. The disproportionate impact of COVID-19 on racial and ethnic minorities in the United States. Clin. Infect. Dis. 72, 703-706 (2021).

44. Viglione, G. Racism and harassment are common in field research-scientists are speaking up. Nature https://doi.org/10.1038/d41586-020-02328-y (2020).

45. Finney, C. Black Faces, White Spaces: Reimagining the Relationship of African Americans to the Great Outdoors (UNC Press Books, 2014). 
46. Dowie, M. Conservation Refugees: The Hundred-Year Conflict between Global Conservation and Native Peoples (MIT Press, 2011).

47. Snook, J. et al. "We're made criminals just to eat off the land": colonial wildlife management and repercussions on Inuit well-being. Sustainability 12, 8177 (2020).

48. Duffy, R. et al. Why we must question the militarisation of conservation. Biol. Conserv. 232, 66-73 (2019).

49. Jansen, J. Decolonisation in Universities: The Politics of Knowledge (Wits Univ. Press, 2019).

50. Janzen, M. Breathing life into the territorial acknowledgement. Trans. Curr. Inq. 16, 74-81 (2019).

51. Kowal, E. et al. Welcome to country: acknowledgement, belonging and white anti-racism. Cult. Stud. Rev. 21, 173-204 (2015).

52. Suchet-Pearson, S., Wright, S., Lloyd, K., Burarrwanga, L. \& Country, B. Caring as country: towards an ontology of co-becoming in natural resource management. Asia Pac. Viewp. 54, 185-197 (2013).

53. Jackson, S. How should scientists acknowledge Indigenous peoples in their research? Catchment to Coast https://catchmenttocoast.org/2018/05/31/ how-should-scientists-acknowledge-indigenous-peoples-in-their-research/ (2018).

54. Stewart, F. Grey owl in the white settler wilderness: "imaginary indians" in Canadian culture and law. Law Cult. Humanit. 14, 161-181 (2018).

55. Levis, C. et al. Persistent effects of pre-Columbian plant domestication on Amazonian forest composition. Science 355, 925-931 (2017).

56. Brearley, L. \& Hamm, T. in Of Other Thoughts: Non-Traditional Ways to the Doctorate 259-278 (SensePublishers, 2013)

57. Brearley, L. in Restorying Indigenous leadership: Wise Practices in Community Development 2nd edn (eds Voyageur, C. et al.) 91-127 (2015)

58. Abimbola, S. The foreign gaze: authorship in academic global health. BMJ Glob. Health 4, e002068 (2019).

59. Eichhorn, M. P., Baker, K. \& Griffiths, M.Steps towards decolonising biogeography. Front. Biogeogr. 12, e44795e (2020).

60. Bohannon, J. Who's downloading pirated papers? Everyone. Science https:// doi.org/10.1126/science.aaf5664 (2016).

61. Vorontsova, M. S. et al. Inequality in plant diversity knowledge and unrecorded plant extinctions: an example from the grasses of Madagascar. Plants People Planet 3, 45-60 (2021).

62. De Vos, A. The problem of 'colonial science'. Sci. Am. https://www. scientificamerican.com/article/the-problem-of-colonial-science/ (2020).

63. Serwadda, D., Ndebele, P., Kate Grabowski, M., Bajunirwe, F. \& Wanyenze, R. K. Open data sharing and the Global South-who benefits? Science 359, 642-643 (2018).

64. The Lancet Global Health Closing the door on parachutes and parasites. Lancet Glob. Health 6, e593 (2018).

65. First Draft of the UNESCO Recommendation on Open Science (UNESCO, 2020); https://unesdoc.unesco.org/ark:/48223/pf0000374837

66. Kukutai, T. \& Taylor, J. in Indigenous Data Sovereignty: Toward an Agenda 1-22 (ANU Press, 2016)

67. Snipp, C. M. in Indigenous Data Sovereignty: Toward an Agenda 39-55 (ANU Press, 2016).

68. Walter, M. \& Andersen, C. Indigenous Statistics: A Quantitative Research Methodology (Routledge, 2016).

69. Toomey, A. Indigenous perspectives on research. YouTube https://www. youtube.com $/$ watch? $=$ uQd95Nq05Rk\&t=357s\&ab_channel=AnneToomey (2015)

70. Toomey, A. H., Knight, A. T. \& Barlow, J. Navigating the space between research and implementation in conservation. Conserv. Lett. 10 , 619-625 (2017).

71. Haraway, D. J. Primate Visions: Gender, Race, and Nature in the World of Modern Science (Psychology Press, 1989).

72. Schell, C. J. et al. Recreating Wakanda by promoting Black excellence in ecology and evolution. Nat. Ecol. Evol. 4, 1285-1287 (2020).

73. Gillman, L. N. \& Wright, S. D. Restoring Indigenous names in taxonomy. Commun. Biol. 3, 609 (2020)

74. Vernes, K. \& Rajaratnam, R. Tall tales misrepresent the real story behind Bhutan's high altitude tigers. The Conversation (23 August 2012); https://theconversation.com/tall-tales-misrepresent-the-real-story-behindbhutans-high-altitude-tigers-8963

75. Mackay, A. W., Adger, D., Bond, A. L., Giles, S. \& Ochu, E. Straight-washing ecological legacies. Nat. Ecol. Evol. 3, 1611 (2019).

76. Kendi, I. X. How to Be an Antiracist (One World, 2019).

77. Pedersen, C. et al. ScIQ: an invitation and recommendations to combine science and Inuit Qaujimajatuqangit for meaningful engagement of Inuit communities in research. Arct. Sci. 6, 326-339 (2020)

78. Shackeroff, J. M., Campbell, L. M. \& Crowder, L. B.Social-ecological guilds: putting people into marine historical ecology. Ecol. Soc. 16, 52 (2011).

79. Ergin, M. \& Alkan, A. Academic neo-colonialism in writing practices: geographic markers in three journals from Japan, Turkey and the US. Geoforum 104, 259-266 (2019).
80. Miriti, M. N., Bailey, K., Halsey, S. \& Harris, N. C. Hidden figures in ecology and evolution. Nat. Ecol. Evol. 4, 1282 (2020).

81. Ramirez, K. S. et al. The future of ecology is collaborative, inclusive and deconstructs biases. Nat. Ecol. Evol. 2, 200 (2018).

82. Ban, N. C., Eckert, L., McGreer, M. \& Frid, A. Indigenous knowledge as data for modern fishery management: a case study of Dungeness crab in Pacific Canada. Ecosyst. Health Sustain. 3, 1379887 (2017).

83. Peterson, G. D. et al. Welcoming different perspectives in IPBES: "Nature's contributions to people" and "Ecosystem services". Ecol. Soc. 23, 39 (2018).

84. Spikes, M. The pressure to assimilate. Science 368, 1506 (2020).

85. Nordling, L. How decolonization could reshape South African science. Nature 554, 159-162 (2018).

86. Harassment, a field study. Nat. Ecol. Evol. 1, 1787-1788 (2017).

87. Demery, A.-J. C. \& Pipkin, M. A.Safe fieldwork strategies for at-risk individuals, their supervisors and institutions. Nat. Ecol. Evol. 5, 5-9 (2021)

88. Polk, M. Transdisciplinary co-production: designing and testing a transdisciplinary research framework for societal problem solving. Futures 65, 110-122 (2015).

89. Nielsen, M. W. et al. Opinion: gender diversity leads to better science. Proc. Natl Acad. Sci. USA 114, 1740-1742 (2017).

90. AlShebli, B. K., Rahwan, T. \& Woon, W. L. The preeminence of ethnic diversity in scientific collaboration. Nat. Commun. 9, 5163 (2018).

91. Lowe, S. J., George, L. \& Deger, J. in Indigenous Research Ethics: Claiming Research Sovereignty Beyond Deficit and the Colonial Legacy (eds George, L. et al.) 275-291 (Emerald Publishing, 2020).

92. Davidson, C. N. The New Education: How to Revolutionize the University to Prepare Students for a World In Flux (Basic Books, 2017).

93. Lach, D. Challenges of interdisciplinary research: reconciling qualitative and quantitative methods for understanding human-landscape systems. Environ. Manag. 53, 88-93 (2014).

94. Lembani, R., Gunter, A., Breines, M. \& Dalu, M. T. B. The same course, different access: the digital divide between urban and rural distance education students in South Africa. J. Geogr. High. Educ. 44, 70-84 (2020).

95. Crenshaw, K. On Intersectionality: Essential Writings (The New Press, 2020).

96. Hedt-Gauthier, B. et al. Academic promotion policies and equity in global health collaborations. Lancet 392, 1607-1609 (2018).

97. DRYFLOR et al. Plant diversity patterns in neotropical dry forests and their conservation implications. Science 353, 1383-1387 (2016).

98. Mollett, S. \& Kepe, T. Land Rights, Biodiversity Conservation and Justice: Rethinking Parks and People (Routledge, 2018).

99. Ramutsindela, M. \& Shabangu, M. in Land Rights, Biodiversity Conservation and Justice 31-48 (Routledge, 2018).

100. Schlosberg, D. \& Collins, L. B. From environmental to climate justice: climate change and the discourse of environmental justice. Wiley Interdiscip. Rev. Clim. Change 5, 359-374 (2014).

101. Reo, N. J. \& Parker, A. K. Re-thinking colonialism to prepare for the impacts of rapid environmental change. Clim. Change 120, 671-682 (2013).

102. Cohen, J. B. Technological advancement and modes of existence in medicinal plant research. Anthropol. South. Afr. 41, 104-114 (2018).

103. Green, L. Contested Ecologies: Dialogues in the South on Nature and Knowledge (HSRC Press, 2013).

104. McPhee, B. W., Benson, R. B. J., Botha-Brink, J., Bordy, E. M. \& Choiniere, J. N. A giant dinosaur from the earliest Jurassic of South Africa and the transition to quadrupedality in early sauropodomorphs. Curr. Biol. 28, 3143-3151.e7 (2018).

105. Plotkin, M. J. Changing the landscape of power (Innovations Case Narrative: Amazon Conservation Team). Innov. Technol. Gov. Glob. 4 13-25 (2009).

106. Plotkin, M. Two complementary approaches to protecting the amazon. Conserv. Biol. 31, 956-958 (2017).

107. Duxbury, N., Garrett-Petts, W. F. \& MacLennan, D. in Cultural Mapping as Cultural Inquiry Ch. 1 (Routledge, 2015).

108. How Kenya's Indigenous Ogiek are using modern technology to validate theirland rights. Africa.com https://africa.com/how-kenyas-indigenous-ogiek-areusing-modern-technology-to-validate-their-land-rights/ (2020).

109. Schuster, R., Germain, R. R., Bennett, J. R., Reo, N. J. \& Arcese, P. Vertebrate biodiversity on Indigenous-managed lands in Australia, Brazil, and Canada equals that in protected areas. Environ. Sci. Policy 101, 1-6 (2019).

110. Adams, M. S. et al. Toward increased engagement between academic and Indigenous community partners in ecological research. Ecol. Soc. 19, 5 (2014).

111. Atlas, W. I. et al. Ancient fish weir technology for modern stewardship: lessons from community-based salmon monitoring. Ecosyst. Health Sustain. 3, 1341284 (2017)

112. Collier-Robinson, L., Rayne, A., Rupene, M., Thoms, C. \& Steeves, T. Embedding Indigenous principles in genomic research of culturally significant species: a conservation genomics case study. N. Z. J. Ecol. 43, 3389 (2019). 
113. Service, C. N. et al. Indigenous knowledge and science unite to reveal spatial and temporal dimensions of distributional shift in wildlife of conservation concern. PLoS ONE 9, e101595 (2014).

114. Housty, W. G. et al. Grizzly bear monitoring by the Heiltsuk people as a crucible for First Nation conservation practice. Ecol. Soc. 19, 70 (2014).

115. Myers, N. \& Liberona, A. Becoming sensor in sentient worlds. Becoming Sensor https://becomingsensor.com/ (2020).

116. Spiegel, S. J. et al. Visual storytelling, intergenerational environmental justice and Indigenous sovereignty: exploring images and stories amid a contested oil pipeline project. Int. J. Environ. Res. Public Health 17, 2362 (2020).

117. Spiegel, S. J. Visual storytelling and socioenvironmental change: images, photographic encounters, and knowledge construction in resource frontiers. Ann. Am. Assoc. Geogr. 110, 120-144 (2020).

118. Khadka, A., Li, C. J., Stanis, S. W. \& Morgan, M.Unpacking the power of place-based education in climate change communication. Appl. Environ. Educ. Commun. 20, 77-91 (2021).

119. Paerregaard, K. Communicating the inevitable: climate awareness, climate discord, and climate research in Peru's highland communities. Environ. Commun. 14, 112-125 (2020).

\section{Acknowledgements}

We thank O. Selomane, P. Mothapo, P. Pillay, A. Plos, A. Koris, L. Green, R. Auerbach and K. Kar Gupta for comments and M. Trisos for assistance with the analysis code. C.H.T. acknowledges funding from the National Socio-Environmental Synthesis Center under funding received from the National Science Foundation (DBI-1639145) and FLAIR fellowship programme-a partnership between the African Academy of Sciences and Royal Society, funded by the UK Government's Global Challenges Research Fund.

\section{Author contributions}

C.H.T., J.A. and M.K. contributed to writing the manuscript. C.H.T. produced the figures

Positionality statement. The authors of this paper all completed undergraduate degrees at institutions in formerly colonized nations of the so-called Global South before undertaking graduate studies and research positions at elite northern universities. These experiences were fundamental to embodied awareness of the inequities of research, learning and teaching. Being aware of multiple shapings of race, gender and class, among others, we acknowledge the complexity of terms such as Indigenous, Western and Global North/South and the difficulty of writing across disciplines and ways of understanding multiple natures ${ }^{103}$. This Perspective is not an easy fix to centuries of violence, but rather a contribution to an ongoing discussion.

\section{Competing interests}

The authors declare no competing interests.

\section{Additional information}

Supplementary information The online version contains supplementary material available at https://doi.org/10.1038/s41559-021-01460-w.

Correspondence should be addressed to C.H.T.

Peer review information Nature Ecology \& Evolution thanks Kate Baker and Zoe Todd for their contribution to the peer review of this work.

Reprints and permissions information is available at www.nature.com/reprints.

Publisher's note Springer Nature remains neutral with regard to jurisdictional claims in published maps and institutional affiliations.

(c) Springer Nature Limited 2021 